\title{
Of the importance of a leaf: the ethnobotany of sarma in Turkey and the Balkans
}

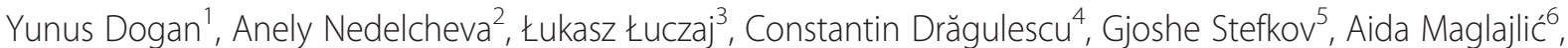
Jonathan Ferrier ${ }^{7,8}$, Nora Papp $^{9}$, Avni Hajdari ${ }^{10}$, Behxhet Mustafa ${ }^{10}$, Zora Dajić-Stevanović ${ }^{11}$ and Andrea Pieroni ${ }^{12^{*}}$

\begin{abstract}
Background: Sarma - cooked leaves rolled around a filling made from rice and/or minced meat, possibly vegetables and seasoning plants - represents one of the most widespread feasting dishes of the Middle Eastern and South-Eastern European cuisines. Although cabbage and grape vine sarma is well-known worldwide, the use of alternative plant leaves remains largely unexplored. The aim of this research was to document all of the botanical taxa whose leaves are used for preparing sarma in the folk cuisines of Turkey and the Balkans.

Methods: Field studies were conducted during broader ethnobotanical surveys, as well as during ad-hoc investigations between the years 2011 and 2014 that included diverse rural communities in Croatia, Bosnia and Herzegovina, Serbia, Kosovo, Albania, Macedonia, Bulgaria, Romania, and Turkey. Primary ethnobotanical and folkloric literatures in each country were also considered.
\end{abstract}

Results: Eighty-seven botanical taxa, mainly wild, belonging to 50 genera and 27 families, were found to represent the bio-cultural heritage of sarma in Turkey and the Balkans. The greatest plant biodiversity in sarma was found in Turkey and, to less extent, in Bulgaria and Romania.

The most commonly used leaves for preparing sarma were those of cabbage (both fresh and lacto-fermented), grape vine, beet, dock, sorrel, horseradish, lime tree, bean, and spinach. In a few cases, the leaves of endemic species (Centaurea haradjianii, Rumex gracilescens, and R. olympicus in Turkey) were recorded.

Other uncommon sarma preparations were based on lightly toxic taxa, such as potato leaves in NE Albania, leaves of Arum, Convolvulus, and Smilax species in Turkey, of Phytolacca americana in Macedonia, and of Tussilago farfara in diverse countries. Moreover, the use of leaves of the introduced species Reynoutria japonica in Romania, Colocasia esculenta in Turkey, and Phytolacca americana in Macedonia shows the dynamic nature of folk cuisines.

Conclusion: The rich ethnobotanical diversity of sarma confirms the urgent need to record folk culinary plant knowledge. The results presented here can be implemented into initiatives aimed at re-evaluating folk cuisines and niche food markets based on local neglected ingredients, and possibly also to foster trajectories of the avant-garde cuisines inspired by ethnobotanical knowledge.

Keywords: Ethnobotany, Balkans, Turkey, Sarma, Gastronomy

\section{Introduction}

Turkey and the Balkans currently represent two exemplar arenas for ethnobiologists, since these regions can be considered both biological and cultural hotspots. Herein, the Balkans are defined as the South-Eastern European territory located south of the Danube-Sava-Kupa river systems line (i.e., the territory that includes the countries of Bosnia

\footnotetext{
*Correspondence: a.pieroni@unisg.it

${ }^{12}$ University of Gastronomic Sciences, Piazza Vittorio Emanuele 9, 12060 Bra/Pollenzo, Italy

Full list of author information is available at the end of the article
}

and Herzegovina, Serbia, Kosovo, Montenegro, Albania, Bulgaria, Macedonia, Greece, as well as the European part of Turkey, a small portion of Romania, and most of Croatia). In the last decade, Turkey and the Balkans have become popular field research locations aimed at documenting traditional environmental knowledge (TEK). Much of this recent research has focused on exploring this region's uncommon, extremely rich, bio-cultural heritage, and also on valorizing local folk knowledge systems into sustainable rural projects that might improve the holistic well-being of the local communities, which in a significant 
portion of the Western Balkans have been recently heavily affected by the most recent Yugoslavian Wars [1].

Most of such studies have focused on folk knowledge related to plants, but some have also investigated the animals-humans nexus [2-4]. Among the ethnobotanical and environmental-anthropological studies published in international journals within the past decade and indexed in important scientific databases (i.e., PubMed, Scopus, WoK), only a few have also analyzed the wild food plant and mushrooms knowledge of the local communities in the Balkans and Turkey. Wild food and mushroom knowledge has been recorded in use among coastal, rural, and isolated mountainous communities in Bosnia [5-7], Bulgaria [8], Macedonia [9,10], Greece [11], Albania [12-16], in the Balkan portions of Croatia [17-19] and Romania [20], as well as in diverse areas of Turkey [21-26]. Moreover, a recent book focusing on Balkan ethnobiology included contributions on the consumption of wild food plants [1].

The term sarma, meaning "wrapped" in Turkish, defines leaves (raw or more often shortly blanched, or kept in salt brine) rolled around a filling made of rice, bulgur and, or minced meat, possibly vegetables and seasoning plants (especially onion), and gently cooked (stewed or boiled) in a pot and generally consumed warm (with meat) or cold (without meat).

Sarma represents a pillar of the traditional cuisines of the former Ottoman territories: Turkey, Persia, the Balkans, the Middle East, and Northern Africa. In some of these contexts, the overarching term dolma is also sometimes used, especially for grape vine leaf-based sarma, although it would be maybe more correct to only apply this term to stuffed vegetables (tomatoes, egg plants, peppers, onions, potatoes, artichoke, zucchini), in which the filling is not completely wrapped or covered by plant tissues.

Sarma has long-represented (at least for four centuries) a crucial festivity dish in many areas of the Ottoman Empire and was present on the menus of palaces and official residences (konaks), where it was prepared as a main course or as a side dish to a main course meat meal [27].

Since the origin of all Turkic populations is rooted in the Central Asiatic pastoralism, generally characterized by a large consumption of meat and dairy products and a low consumption of vegetables, gastronomy historians agree that sarma preparations may have possibly developed after Turks settled in Anatolia, where their diet was enriched by a large number of cultivated vegetables [26], whereas the Ottoman cuisine is surely the result of a complex metissage and interactions between the Turkish cuisine and a number of other cuisines native to the surrounding territories (notably the Arabic, Persian, the Mediterranean, and East European cuisines) [28-32].

According to the German traveller and merchant Hans Dernschwam, who visited Istanbul between 1552 and 1555, dolma and sarma were then commonly consumed, and fresh grape vine leaves were sold in many places for preparing sarma. Dernschwam's diaries note that the filling of sarma was made from meat and that sarma was cooked together with unripe, sour plums [33]. Other historical sources testify that in 1640 cabbage sarma was sold in Istanbul, while in 1660 cabbage sarma was on the menu of some dinner parties of wealthy men [26].

Turkish cookbooks written in the 19th Century underline the importance of a balance between the sour and sweet tastes in sarma [34], a principle that was probably borrowed from the Persian cuisine. In addition to the inclusion of minced onions occurring in the filling, the wrapped leaves were cooked adding lemon, and sometimes also unripe plums, sour apples or their juice, unripe grapes, pomegranate or sumac syrups, or even dried sour cherries.

The aims of this work were: (1) to review all unpublished or partially published data collected by the authors in Turkey and the Balkans (i.e., in Bosnia and Herzegovina, Serbia, Macedonia, Bulgaria, Albania, as well as in Croatia and Romania, which - despite the fact they have only one portion of their territories located in the Balkans - were considered in their entirety); (2) to review the same plants used for preparing sarma from primary folkloric, ethnobotanical, and gastronomic literature from the same countries; and (3) to compare the geographic and cross-cultural diversity of sarma in the considered countries.

\section{Methods}

\section{Field studies}

Field studies on the use of plants used as wrapping material for sarma were conducted during broader ethnobotanical field studies and also via a few ad hoc investigations conducted by the authors in the years 2011 to 2014 in the following regions and countries (Figure 1): Dalmatia, Croatia ( $\mathrm{E})$; Northern and Central Bosnia and Southern Herzegovina (AM, JF, and $Ł €$, respectively); Central and Southern Serbia (ZDS); Kosovo (BM, AH); North, Eastern and Southern Albania (AP); Central and Western Macedonia (SG, AP); Western and Central Bulgaria (AN); Transylvania (CD, NP), Dobruja (AN, YD, AP), Moldavia (AP), and Maramureş regions, Romania ( $\mathrm{LE}$ ); and in the Aegean and Central Anatolian Turkey (YD).

Informants were asked to mention all plants, whose leaves were used as wrapping material for preparing homemade sarma. Ethical guidelines drafted by the International Society of Ethnobiology (http://www.ethnobiology.net) and American Anthropological Association (www.aaanet.org) were rigorously followed and Prior Informed Consent (PIC) was always required before each interview.

Plants were taxonomically identified by the respective researchers and plant nomenclature followed standards set by The Plant List [35].

\section{Literature review}

Additionally, published ethnobotanical works, as well as a few folkloric references and gastronomic literature based on field investigations, were considered for the following 
countries: Albania and Kosovo [12-16,36-39], Bosnia and Herzegovina [5-7,40-43], Bulgaria [8,44-50], Croatia [17-19,51-53], Macedonia [9,10], and Romania [29,54-69]; moreover, for Turkey, ethnobotanical data both published in international and national scholarly journals, as well as those arising from unpublished Master's and PhD theses were considered [21-26,70-103].

Again, plant nomenclature followed the standards set by The Plant List [35].

\section{Results and discussion}

\section{Biodiversity of sarma}

Table 1 reports all the plant taxa, whose leaves have been documented to be used as wrapping material for sarma. Eighty-seven taxa were found to represent the Turkish and Balkan sarma plant heritage, whose knowledge is retained by women. In the list, wild plants were predominant (62\%).

Basic ingredients for the stuffing always includes meat or rice, (sautéed) onions, and sometimes, especially in more rural areas, chopped vegetables too (and especially wild vegetables in Moldavia during the spring Orthodox Lent period); in Turkey and Bulgaria bulgur (made from the grouts of diverse wheat species), cooked beans as well as urov (Vicia sativa) can be used in the filling.

In Bulgaria, crushed walnuts may be added to the filling. In Turkish cuisine filling ingredients may include pine kernels (Pinus pinea), Black Corinth (Vitis vinifera), blackcurrants (Ribes nigrum), and even mastic (resin of Pistacia lentiscus). An old tradition in Turkey was to also add sour cherries in the filling; however, this tradition is barely alive with only a few traditional restaurants serving the product.

The listed taxa belong to 50 genera and 27 families, with the predominance of Polygonaceae (15\%), Malvaceae (11\%), Amaranthaceae (11\%), Asteraceae (10\%), and Brassicaceae (9\%). The largest number of taxa was recorded in the genera Rumex (11), Beta (5), Alcea (4), Brassica (4), Malva (3) and Arum (3).

Among them, herbaceous plants represented the majority of the recorded plants (65), while trees (10) and shrubs (2) were mostly from the Rosaceae, Moraceae, Betulaceae and Malvaceae families, while four species were represented by vines.

In Moldavia chopped cabbage and dill branches are often put at the bottom of the pot where sarma will be cooked, often adding a pieces of cured pork meat (bacon); in Bulgaria plums are put between the diverse sarma units.

While in Moldavia it is customary to add in the cooking pot also home-made borşs (lacto-fermented wheat bran in water) or unripe grapes (previously cooked in water), in order to provide some sourness (this is not practiced in the case of sauerkraut sarma), while the custom to add lemon slices in the pot seems to be prevalent in Turkey and Southern Albania.

Turkey and Southern Albania sarma are typically small and have a cigar-like shape. In Bulgaria sarma are larger (Figure 2) and resemble small balls, while in Romania and the other countries may have diverse dimensions. Cigar-like sarma are considered appropriate for special guests in the

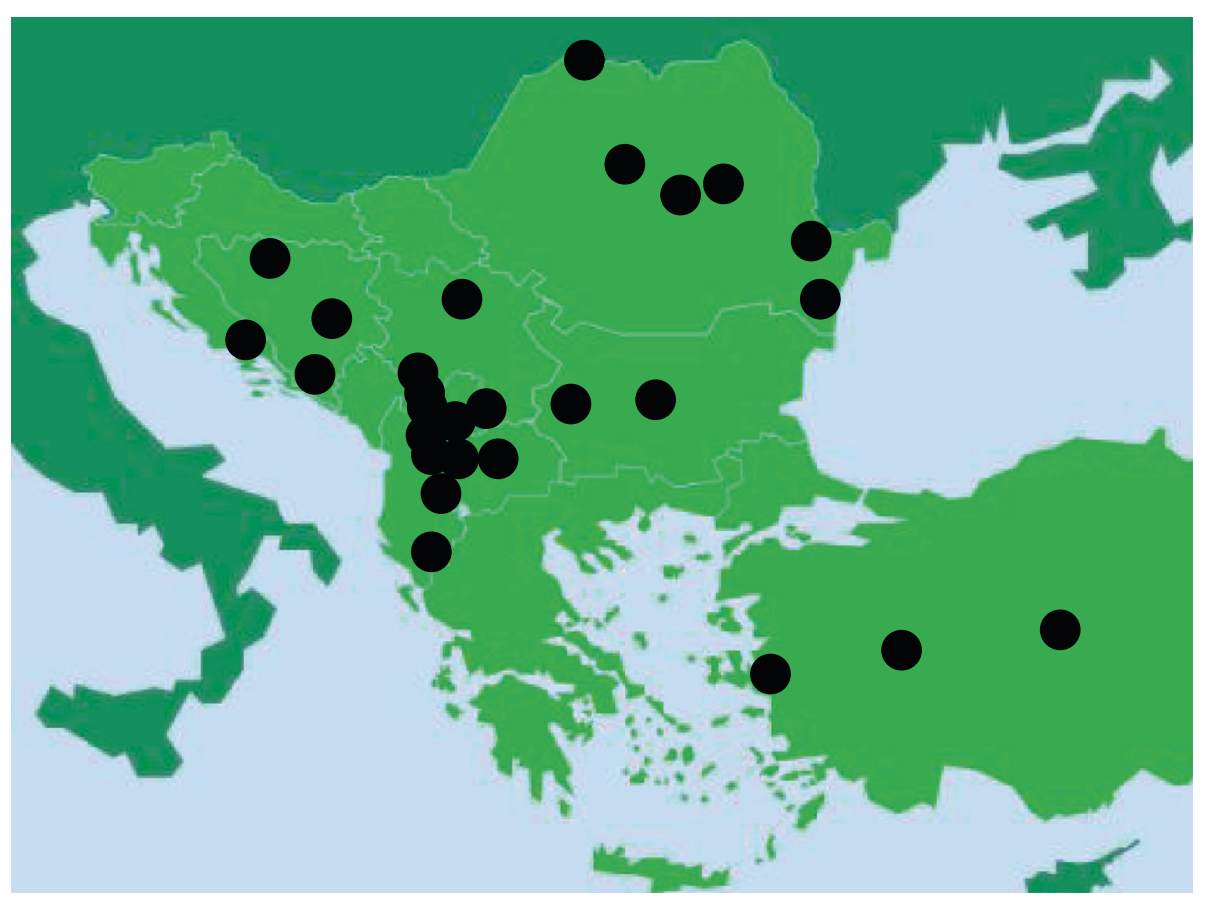

Figure 1 The study sites. 
Table 1 Plants whose leaves are used for preparing sarma in the studied areas and considered countries

\begin{tabular}{|c|c|c|c|c|c|}
\hline Botanical taxon and English common name & $\begin{array}{l}\text { Botanical } \\
\text { family }\end{array}$ & Status & Local name(s) & Area(s) of use & Source(s) \\
\hline $\begin{array}{l}\text { Alcea flavovirens (Boiss. and Buhse.) Iljin } \\
\text { Yellow-Green Hollyhock }\end{array}$ & Malvaceae & W & hero, hiro & Turkey: East Anatolia & [78] \\
\hline $\begin{array}{l}\text { Alcea hohenackeri (Boiss. and Huet.) Boiss. } \\
\text { Hohenacker's Hollyhock }\end{array}$ & Malvaceae & W & fatma gülü, gül hatmi, hero, hiro & Turkey: East Anatolia & [94] \\
\hline $\begin{array}{l}\text { Alcea kurdica (Schlecht) Alef Kurdish } \\
\text { Hollyhock }\end{array}$ & Malvaceae & W & hero, heru & Turkey: East Anatolia & {$[78,95]$} \\
\hline Alcea rosea L. Common Hollyhock & Malvaceae & W & ружа & Bulgaria: Osogovo Mt. & AN \\
\hline \multirow[t]{2}{*}{ Allium ampeloprasum L. Leek } & Amaryllidaceae & C & pırasa & Turkey: Izmir & YD \\
\hline & & & prasa & Bosnia and Herzegovina: Northern Bosnia & AM \\
\hline Allium ursinum $\mathrm{L}$. Ramsons & Amaryllidaceae & W & левурда & Bulgaria: Lovech area & AN \\
\hline Amaranthus viridis L. Green Amaranth & Amaranthaceae & W & delisirken, hoşguran, kızılca mancar, semlik & Turkey: Şırnak & [76] \\
\hline Arctium minus (Hill) Bernh. Lesser Burdock & Asteraceae & W & dulavratotu, galabah & Turkey: Erzurum & [72] \\
\hline $\begin{array}{l}\text { Arctium platylepis (Boiss. \& Bal.) Sosn. ex Grossh. } \\
\text { Halemhort }\end{array}$ & Asteraceae & W & baldikeni, deve tabanı & Turkey: NW Anatolia & [103] \\
\hline $\begin{array}{l}\text { Armoracia rusticana P.Gaertn., B.Mey \& } \\
\text { Scherb. Horseradish }\end{array}$ & Brassicaceae & C & хрян & Bulgaria: Plovdiv area & AN \\
\hline
\end{tabular}

Arum conophalloides Kotschy ex Schott

hrean, hrin ${ }^{\mathrm{UK}}$, torma ${ }^{\mathrm{HU}}$

\section{hren, kren, peH}

Araceae $\quad$ W y yllan bıcağı, yılan yastığı

Araceae W sarmalık, yılan bıçağı, yılan ekmeği, yılan pancarı

Araceae $\quad$ W y y $\quad$ ylan ekmeği, yllan yastı̆̆ı

Amaranthaceae C градинска лобода

Amaranthaceae W/C розова лобода

Amaranthaceae C mancar, süt mancar,

Amaranthaceae $C$ pazı

Beta vulgaris L. ssp. vulgaris convar. cicla Beet/Chard

Beta vulgaris L. ssp. vulgaris convar. vulgaris var. altissima Sugar Beet

Beta vulgaris L. Ssp. vulgaris convar. vulgaris var. vulgaris Beetroot

$\begin{array}{ll}\text { Amaranthaceae C } & \begin{array}{l}\text { blitva/блитва } \\ \text { şekerpancarı, cukorrépa }\end{array} \\ \text { Amaranthaceae } \mathrm{C} & \text { burak }^{\mathrm{UK}} \text {, cékla }\end{array}$

цвекло

цвекла

pancar
Romania: Dobruja, Transylvania, Maramureș ${ }^{\mathrm{UK}}$

Bosnia and Herzegovina and Serbia: diverse areas

Turkey: South Anatolia

Turkey: South and South-Eastern Anatolia

Turkey: West and Central Anatolia

Bulgaria: all over the country

Bulgaria: all over the country

$A N, A P, Y D, C D$, Łt

$A M, J F, Z D S$

[77]

$[72,77]$

[22]

[47], AN

$[8,47]$

[26]

[93], YD

Turkey: Duzce, Turhal, Malatya

Bosnia Herzegovina and Serbia: diverse areas

$A M, ~ Ł t, Z D S$

Turkey: Afyon

Romania: Szekely Land

Romania: Moldaviaomania: Szekely Land

$N P, Y D$

[64], ŁŁ

Romania: Moldavia

Maramureș area

Bulgaria: Bansko, Pirin Mt., Karlovo

[47], AN

Serbia: diverse areas

ZDS

Turkey: Izmir, Malatya 
Table 1 Plants whose leaves are used for preparing sarma in the studied areas and considered countries (Continued)

\begin{tabular}{|c|c|c|c|}
\hline Brassica oleracea Acephala group Kale & Brassicaceae & C & kara lahana \\
\hline \multirow{6}{*}{$\begin{array}{l}\text { Brassica oleracea Capitata Group (both fresh } \\
\text { and lacto-fermented [sauerkraut]) Cabbage }\end{array}$} & Brassicaceae & C & lahana \\
\hline & & & прясно зеле, кисело зеле \\
\hline & & & kupus/купус \\
\hline & & & зелка, расол, купус \\
\hline & & & lakna, liakra \\
\hline & & & curechi, káboszta $^{\mathrm{HU}}$, káposzta ${ }^{\mathrm{HU}}$, varză \\
\hline Brassica oleracea L. var. gongylodes Kohlrabi & Brassicaceae & C & алабаш, гулия \\
\hline Brassica rapa L. var. rapa Turnip & Brassicaceae & C & kırmızı çükündür \\
\hline Caltha palustris L. Marsh Marigold & Ranunculaceae & W & bulbuci de baltă, calcea calului \\
\hline Campanula sclerotricha Boiss. Bellflower & Campanulaceae & W & büyük köklü, çançiçeği, nermedenk \\
\hline Centaurea haradjianii Wagenitz & Asteraceae & W & kaputkulak \\
\hline Cercis siliquastrum L. Judas Tree & Fabaceae & W/C & Erguvan \\
\hline Cirsium arvense (L.) Scop. Creeping Thistle & Asteraceae & W & köygöçüren, köygöçerten \\
\hline Colocasia esculenta (L.) Schott Taro & Araceae & C & göleğez \\
\hline Convolvulus stachydifolius Choisy & Convolvulaceae & W & sermaşık, sarmaşık \\
\hline \multirow[t]{2}{*}{ Corylus avellana L. Hazelnut* } & Betulaceae & C & findık \\
\hline & & W/C & leithi \\
\hline Corylus maxima Mill. Filbert & Betulaceae & C & findık \\
\hline \multirow[t]{2}{*}{ Cydonia oblonga Mill. Quince } & Rosaceae & C & ayva \\
\hline & & & ftoi \\
\hline $\begin{array}{l}\text { Heracleum trachyloma Fisch. \& C.A. Mey. Downy } \\
\text { cow-parsnip }\end{array}$ & Apiaceae & W & baldırgan \\
\hline \multirow[t]{2}{*}{ Lactuca sativa L. Lettuce } & Asteraceae & C & marul \\
\hline & & & маруля \\
\hline Malva neglecta Wallr. Dwarf Mallow & Malvaceae & W & $\begin{array}{l}\text { ebegümeci, ebemgümeç, ebemövmeci, } \\
\text { tolık, tolk }\end{array}$ \\
\hline Malva nicaeensis All. French Mallow & Malvaceae & W & develik, ebegümeci \\
\hline Malva sylvestris L. Mallow & Malvaceae & W & develik, ebegümeci \\
\hline Morus alba L. White Mulberry & Moraceae & C & akdut, dut, tuye \\
\hline Morus nigra L. Black Mulberry & Moraceae & C & dut, karadut, tuye \\
\hline
\end{tabular}

Turkey: Black Sea Region, Duzce, Izmit

$[81,88,97]$

Turkey: all over the country

YD

Bulgaria: all over the country

$[46,47,50]$, AN

Bosnia Herzegovina, Croatia, and Serbia: all over the AM, JF, ŁŁ, ZDS country (in Serbia quite exclusively used only lacto-fermented)

Macedonia: all over the country

Kosovo and Albania: all over the country

Romania: all over the country

$C D, N P$

Bulgaria: Rhodopes Mt., Dobrostan

[46,47], AN

Turkey: Düzce

[97]

Romania: Moldavia

$[59,67]$

Turkey: Hakkari

Turkey: South Anatolia

Turkey: diverse areas

Turkey: West and Central Anatolia

Turkey: Adana, Antalya

Turkey: Cizre

Turkey: Duzce, Malatya

Kosovo: Pristina area

Turkey: Duzce, Malatya

Turkey: Malatya

Albania: Mt. Korab

Turkey: East Anatolia

[22]

YD

[76]

[97], YD

$\mathrm{BM}, \mathrm{HA}$

[97], YD

YD

[9]

[103]

Turkey: West Anatolia, Malatya

YD

Bulgaria: Sofia area, Plovdiv area

AN

Turkey: all over the country

Turkey: Çanakkale

Turkey: West Anatolia

[22,75]

Turkey: East, West and Central Anatolia [22,99], YD

Turkey: all over the country _ [22,99], YD

Moraceae 
Table 1 Plants whose leaves are used for preparing sarma in the studied areas and considered countries (Continued)

\begin{tabular}{|c|c|c|c|c|c|}
\hline Morus rubra L. Red Mulberry & Moraceae & $C$ & mordut, kırmızı dut & Turkey: West and Central Anatolia & {$[22], Y D$} \\
\hline Onopordum illyricum L. Illyrian Thistle & Asteraceae & W & deli kenger, dolma kenkeri, eşek dikeni & Turkey: Muğla & [101] \\
\hline $\begin{array}{l}\text { Pelargonium quercetorum Agnew Turkish } \\
\text { Pelargonium }\end{array}$ & Geraniaceae & W & tolk & Turkey: Hakkari & [78] \\
\hline $\begin{array}{l}\text { Petasites hybridus (L.) G. Gaertner, B. Meyer and } \\
\text { Scherb. Butterbur }\end{array}$ & Asteraceae & W & galdirel, kaldırek, kaldirek & Turkey: Manyas & [98] \\
\hline \multirow[t]{4}{*}{ Phaseolus vulgaris L. Bean } & \multirow[t]{4}{*}{ Fabaceae } & \multirow[t]{4}{*}{$C$} & fasülye & Turkey: West and East Anatolia, Malatya & [102], YD \\
\hline & & & fasole & Romania: Bacau area & AP \\
\hline & & & грав ${ }^{\mathrm{MK}}$ & Albania: Gollobordo ${ }^{\mathrm{MK}}$ & [13] \\
\hline & & & grah, mohune & Bosnia and Herzegovina: Sarajevo area & $J F$ \\
\hline Phytolacca americana L.* Pokeweed & Phytolaccaceae & W & крмус & Macedonia: Strumica area & GS \\
\hline Plantago lanceolata L. Narrowleaf Plantain & Plantaginaceae & W & sinirliot & Turkey: West and Central Anatolia & {$[22,93]$} \\
\hline Plantago major L. Broadleaf Plantain & Plantaginaceae & W & $\begin{array}{l}\text { belgheviz, damar otu, kesikotu, sinirotu, } \\
\text { yara otu }\end{array}$ & Turkey: East Anatolia, Izmit, Ordu, Samsun, & {$[72,81,95]$} \\
\hline Primula veris L. Cowslip & Primulaceae & W & $\begin{array}{l}\text { aguliçe, zgjerifet, lulë, lule dashi, lule deshi, } \\
\text { lule verdhë, qingji, zgjirifet }\end{array}$ & Albania: Mt. Korab & [9] \\
\hline Primula vulgaris Huds. Primrose & Primulaceae & W & ak meneksen, çuha çiçeği & Turkey: South Anatolia & {$[87,77]$,} \\
\hline Prunus avium L. Cherry & Rosaceae & C & kiraz & Turkey: Malatya, Sakarya & {$[84], Y D$} \\
\hline Raphanus raphanistrum L. Wild Radish & Brassicaceae & W & turpotu & Turkey: West and Central Anatolia, Kahrmanmaras & {$[22,87]$} \\
\hline Reynoutria japonica Houtt. Japanese Knotweed & Polygonaceae & W & bambus & Romania: Maramureș & {$[64], \nvdash t$} \\
\hline Rheum ribes L. Syrian Rhubarb & Polygonaceae & W & işgın & Turkey: East Anatolia & [103] \\
\hline Ribes nigrum L. Blackcurrent & Grossulariaceae & $C$ & coacăz negru & Romania: Transylvania & [67] \\
\hline Rubus idaeus L. Raspberry & Rosaceae & C & maline & Bosnia and Herzegovina: Sarajevo area & $J F$ \\
\hline Rubus caesius L. Dewberry & Rosaceae & W & капина & Bulgaria: Lovech area & [47] \\
\hline \multirow[t]{4}{*}{ Rumex acetosa L. Sorrel } & \multirow[t]{4}{*}{ Polygonaceae } & \multirow[t]{4}{*}{ W } & ekşi labada, ekşilküçük labada & Turkey: West and Central Anatolia & [22] \\
\hline & & & киселец & Bulgaria: Rhodopes Mt. area & [8] \\
\hline & & & uthullaçe & Kosovo: Pristina area & $\mathrm{BM}, \mathrm{AH}$ \\
\hline & & & киселица & Serbia: South and Central regions & ZDS \\
\hline Rumex acetosella L. Red Sorrel & Polygonaceae & W & ebem ekşisi, ekşikulak, kuzukulağı, tırşık & Turkey: East Anatolia & [99] \\
\hline \multirow[t]{2}{*}{ Rumex alpinus L. Alpine Dock } & \multirow[t]{2}{*}{ Polygonaceae } & \multirow[t]{2}{*}{ W } & dağ pazısı, ışıın & Turkey: East Anatolia, Afyon & {$[72,99]$} \\
\hline & & & ştevia stânelor & Romania: Transylvania & [67] \\
\hline Rumex conglomeratus Murray Sharp Dock & Polygonaceae & W & labada, kuzukulağı, tırşo, tirşik & $\begin{array}{l}\text { Turkey: South, East and South-eastern Anatolia, } \\
\text { Manyas }\end{array}$ & {$[71,76,86,94,98]$} \\
\hline
\end{tabular}


Table 1 Plants whose leaves are used for preparing sarma in the studied areas and considered countries (Continued)

\begin{tabular}{|c|c|c|c|c|c|}
\hline \multirow[t]{3}{*}{ Rumex crispus L. Curly Dock } & Polygonaceae & W & efelek, efelik, kıvırcık labada, tırşo,labada, tirşik & Turkey: West and Central Anatolia, Bursa, Cizre & $\begin{array}{l}{[22,23,25,72,76,80,} \\
84,90], \text { YD }\end{array}$ \\
\hline & & & штавеј & Macedonia: all over the country & GS \\
\hline & & & штаваљ & Serbia: all over the country & ZDS \\
\hline Rumex gracilescens Rech. & Polygonaceae & W & acımancar, efelek, göylek, güyrek & Turkey: Ankara & {$[26,91]$} \\
\hline \multirow[t]{2}{*}{ Rumex obtusifolius L. Broad-Leaved Dock } & Polygonaceae & W & yabani labada & Turkey: West and Central Anatolia & {$[22], Y D$} \\
\hline & & & ştevie & Romania: Transylvania & {$[67]$} \\
\hline Rumex olympicus Boiss. & Polygonaceae & W & ebelek, ilabada & Turkey: Bursa & [72] \\
\hline \multirow[t]{5}{*}{ Rumex patientia L. Patience Dock } & Polygonaceae & W & $\begin{array}{l}\text { akıllı labada, at kulağı, efelek, evelik, göbede, } \\
\text { güylek, labada }\end{array}$ & Turkey: Thrace, Anatolia & $\begin{array}{l}{[22-24,80,85,93,98],} \\
\text { YD }\end{array}$ \\
\hline & & & лапад & Bulgaria: all over the country & {$[8,47]$, AN } \\
\hline & & & $\begin{array}{l}\text { atkulak }{ }^{\top A}, \text { dragomir, măcrisul cucului, ştevie } \\
\text { de grădină, ščava }\end{array}$ & Romania: Transylvania, Dobruja ${ }^{\mathrm{TA}}{ }^{\text {, Maramureș }}{ }^{\mathrm{UK}}$ & {$[64], A N, A P, \measuredangle t, Y D$} \\
\hline & & & лапад & Bulgaria: all over the country & {$[8,47]$, AN } \\
\hline & & & зеље & Serbia: diverse areas & ZDS \\
\hline Rumex pulcher L. Fiddle Dock & Polygonaceae & W & labada, ilabada & Turkey: Çanakkale, Izmit & {$[75,81]$} \\
\hline Rumex tuberosus L. Swollen Sorrel & Polygonaceae & W & efelek, kuzukıkırdağı & Turkey: East Anatolia, Eskişehir & {$[70,78,80,95]$} \\
\hline Salvia forskaohlei L. Forskhal's Sage & Lamiaceae & W & şalba & Turkey: unspecified Asia Minor & [79] \\
\hline Salvia poculata Náb. & Lamiaceae & W & bareş, öküzpörçüğü, ezmangag & Turkey: East Anatolia & {$[78,95]$} \\
\hline Salvia sclarea L. Clary Sage & Lamiaceae & W & tüylü adaçayı, misk adaçayı, pune, ayıkulağı & Turkey: East Anatolia & [99] \\
\hline Sinapis arvensis L. Field Mustard & Brassicaceae & W & hardalotu & Turkey: Tokat & [93] \\
\hline Smilax excelsa L. Smilax & Smilacaceae & W & melevcen & Turkey: unspecified Asia Minor & [79] \\
\hline \multirow[t]{3}{*}{ Spinacia oleracea L. Spinach } & Amaranthaceae & C & ıspanak & Turkey: West Anatolia & YD \\
\hline & & & спанак & Bulgaria: Sofia area, Plovdiv area & AN \\
\hline & & & špinat, španać, спанаћ & Bosnia and Herzegovina and Serbia: diverse areas & AM, ZDS \\
\hline Solanum tuberosum L. Potato & Solanaceae & C & компири ${ }^{\mathrm{MK}}$ & Albania: Gollobordo ${ }^{\mathrm{MK}}$ & [13], AP \\
\hline Silybum marianum (L.) Gaertn. Milk Thistle & Asteraceae & W & devedikeni & Turkey: diverse areas & [103] \\
\hline $\begin{array}{l}\text { Symphytum kurdicum Boiis. and Hausskn. Kurdish } \\
\text { Comfrey }\end{array}$ & Boraginaceae & W & karakafesotu, ezmangag & Turkey: Hakkari & [78] \\
\hline Tilia cordata Miller Small-Leaved Lime & Malvaceae & CN & blini & Kosovo: Pristina area & $\mathrm{BM}, \mathrm{AH}$ \\
\hline $\begin{array}{l}\text { Tilia cordata Miller and T. platyphyllos Scop. } \\
\text { Small- and Large-Leaved Lime }\end{array}$ & Malvaceae & CM & tei & Romania: diverse areas & [67], AP \\
\hline Tilia tomentosa Moench Silver Lime & Malvaceae & CM & липа & $\begin{array}{l}\text { Bulgaria: Lovech and Tsarevo areas; Turkey: } \\
\text { diverse areas }\end{array}$ & {$[47,103]$, AN } \\
\hline Trachystemon orientalis (L.) G. Don & Boraginaceae & W & galdirik, hodan, ispit, kaldırık, kaldurak otu & Turkey: diverse areas & {$[83,93,97], Y D$} \\
\hline
\end{tabular}


Table 1 Plants whose leaves are used for preparing sarma in the studied areas and considered countries (Continued)

\begin{tabular}{|c|c|c|c|c|c|}
\hline \multirow[t]{3}{*}{ Tussilago farfara L. Coltsfoot } & \multirow[t]{3}{*}{ Asteraceae } & \multirow[t]{3}{*}{ W } & öksürükotu & Turkey: West and Central Anatolia, Kastamonu & {$[22,72]$} \\
\hline & & & $\begin{array}{l}\text { martilapi }{ }^{\mathrm{HU}}{ }_{\text {, fehérhátút }}^{\mathrm{HU}}, \text { lapu }^{\mathrm{HU}} \text {, podbal, } \\
\text { podbielina }^{\mathrm{PO}} \text { tőltike }^{\mathrm{HU}}\end{array}$ & Romania: diverse areas & $\begin{array}{l}{[60,67-69], A P, C D,} \\
\lfloor t, N P\end{array}$ \\
\hline & & & podbel, podbjel, подбел & $\begin{array}{l}\text { Bosnia and Herzegovina and Serbia: diverse areas } \\
\text { (in Serbia rarely used) }\end{array}$ & $J F, Z D S$ \\
\hline \multirow[t]{3}{*}{ Urtica dioica L. Nettle } & \multirow[t]{3}{*}{ Urticaceae } & \multirow[t]{3}{*}{ W } & Isıran & Turkey: South-eastern Anatolia & [74] \\
\hline & & & коприва & Serbia: diverse areas & ZDS \\
\hline & & & hitha, hejtha & Albania: Mt. Korab & [9] \\
\hline Vicia faba L. & Fabaceae & $\mathrm{C}$ & бакла & Bulgaria: Karlovo area & {$[47]$} \\
\hline Vitis labrusca L. Fox Grape & Vitaceae & $\mathrm{C}$ & rrush me erë & Albania: Mt. Korab & [9] \\
\hline Vitis sylvestris Gmelin Wild Grape & Vitaceae & W & çivek, deliasma, lazüzümü & Turkey: Yalova & {$[100]$} \\
\hline \multirow[t]{6}{*}{ Vitis vinifera L. Grape } & \multirow[t]{6}{*}{ Vitaceae } & \multirow[t]{6}{*}{ C } & asma, tiri, jur & Turkey: all over the country & $\begin{array}{l}{[78,83,87,88} \\
90,95], Y D\end{array}$ \\
\hline & & & лоза & Bulgaria: all over the country & {$[8,46,47,50]$} \\
\hline & & & лоза & Macedonia: all over the country & GS \\
\hline & & & rrushi & Kosovo and Albania: all over the countries & $\mathrm{AH}, \mathrm{AP}$ \\
\hline & & & viță de vie, szőlöHU & Romania: diverse areas & {$[65,67,96], C D, N P$} \\
\hline & & & loza/лоза & Serbia, Bosnia Herzegovina, and Croatia: diverse areas & $A M, J F, ~ Ł Ł, ~ Z D S$ \\
\hline
\end{tabular}

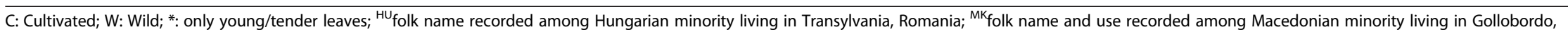

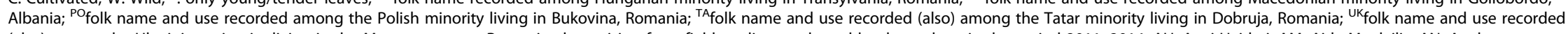
(also) among the Ukrainian minority living in the Maramureş area, Romania; data arising from field studies conducted by the authors in the period 2011-2014: AH: Avni Hajdari; AM: Aida Maglajlic; AN: Anely Nedelcheva; AP: Andrea Pieroni; BM: Behxhet Mustafa; CG: Constantin Drăgulescu; GS: Gjoshe Stefkov; JF: Jonathan Ferrier; Łt: Łukasz Łuczaj; NP: Nora Papp; YD: Yunus Dogan; ZDS: Zora Dajić-Stevanović. 

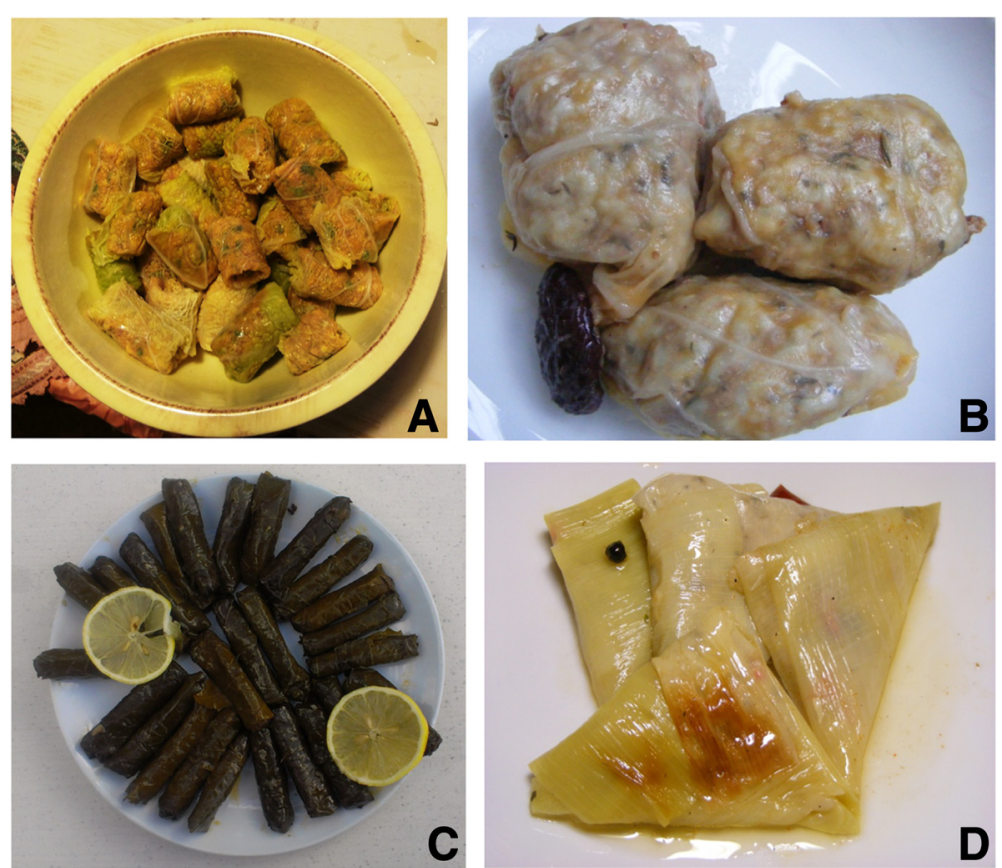

Figure 2 Diversity of sarma preparations in Turkey and the Balkans; A - Brassica oleracea (just before the cooking process; Romania); B - Brassica oleracea (Bulgaria); C - Vitis vinifera (Turkey); D - Allium ampeloprasum (Turkey).

Romanian Moldavia; in this specific case, vine-grape, lime tree, or bean leaves-based cigar-shaped sarma are cooked in a group of 6-7 unities, wrapped within larger leaves of cabbage, which are later removed before consuming the sarma.

In Moldavia also, a very large cabbage sarma exists during the diverse Orthodox Lenten fasting periods. The filling in the Moldavian case is made by a large amount of rice, crashed walnuts, sautéed onions, roughly chopped onions, cabbage, parsnips or carrots, and seasoned with small amounts of ground celery, parsley roots, dill, and whole pepper grains.

Sarma prepared from cultivated leek (Allium ampeloprasum s.l.) are different from other sarma and usually have a triangular shape (Figure 2). This type of sarma is part of traditional cuisine found only in some areas of Turkey (e.g. the Aegean region); sometimes sarma made by cabbage, kale, dock, and beet can be also prepared in triangular shape.

In general, preparing sarma requires special artisanal women expertise and is a time consuming process. Because of the newly introduced lifestyles and maybe changing social role of women, sarma is slowly and gradually disappearing from the home cuisine of the studied areas. In Turkey however, sarma is still available on the market and a number of women earn money by taking orders at home.

At the same time, it should be noted that in the last decades an apparatus has become commercially available in Turkey that makes it easier to roll the leaves around the filling (esp. grape vine leaves, Figure 3). This tends to produce thin sarma having a standardized shape.
Figure 4 shows the most widely used sarma leaves in the considered countries. Cabbage and grape vine, and to a minor extent, beet, dock and sorrel, lime tree, spinach, beans, and horseradish are plants that have been reported to have been used in at least four countries.

\section{Botany and sensory characteristics of sarma's leaves}

According to our sources, three principal criteria guide the rationale behind the use of plant leaves for sarma: (1) leaves have to be large enough (ideally the size of one's palm) to wrap what is considered to be a proper amount of the filling. Sarma is generally eaten in one or two bites, or, even more as in the case of the large cabbage sarma prepared during the Orthodox Lent in Moldavia; (2) leaves must be strong enough to not degenerate during the cooking process while retaining the flavour of the filling; and (3) leaves may add a specific texture (e.g., bean and grape vine leaves) or taste to the filling (e.g., lime tree leaves, cabbage, horseradish, coltsfoot, leek). The aforementioned requirements of leaves used for sarma, can be linked with some botanical-morphological and, or phytochemical characteristics.

Concerning the first criterion, which dictates the general rule of "one leaf lamina - one sarma", we have recorded only some exceptions among cultivated leafy vegetables: cabbage outer leaves are sometimes divided into two or three parts, which individually wrapped around the filling; the same may be (more rarely) done with leaves of spinach, beets, horseradish, or lettuce. 


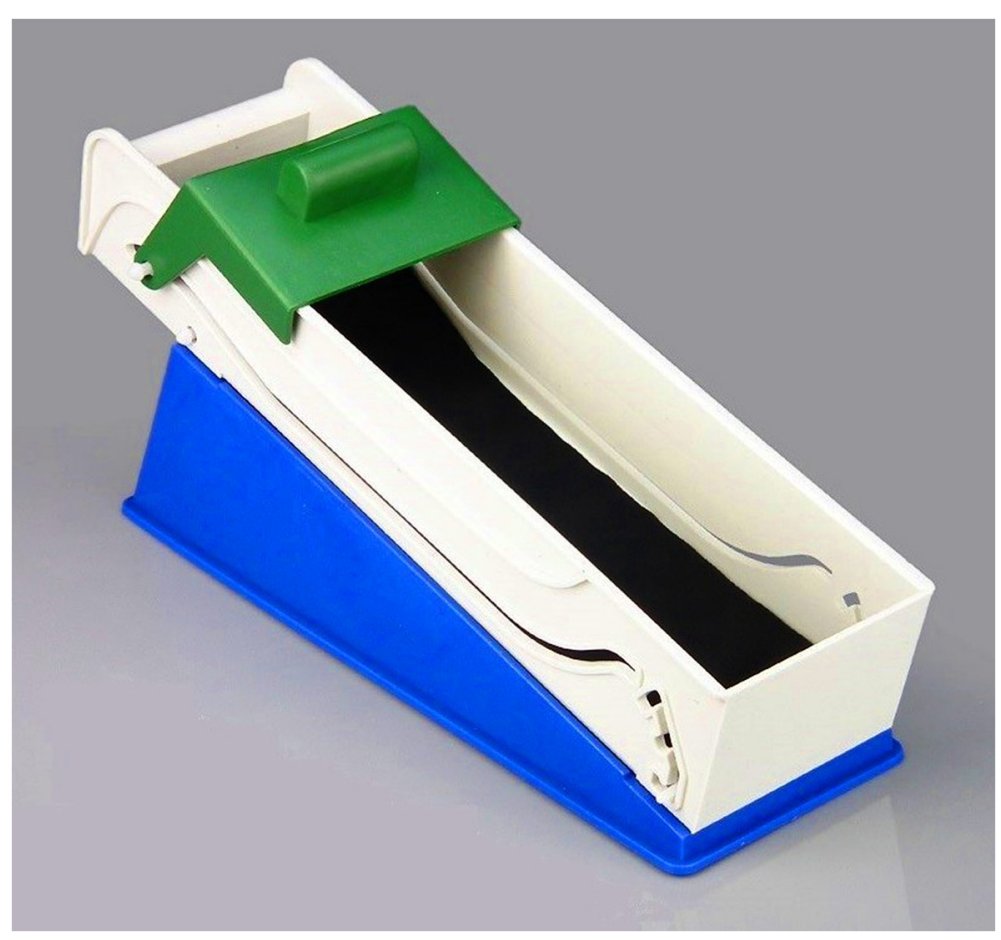

Figure 3 Turkish "modern" apparatus for making sarma.

Leaf shape is variable but mostly consist of round (Brassica oleracea), reniform/kidney (Tussilago farfara), ovate (Corylus avellana), cordate (Smilax excelsa, Tilia tomentosa), elliptic (Allium ursinum), or lanceolate (Armoracia rusticana, Rumex spp., Arum spp.) shapes, including various intermediate forms.

The dominant leaf types make it possible to wrap cigar-shaped sarma, while for a few species rosette (Brassica oleracea, Cirsium arvense, Primula spp., Plantago spp.), basal (Rumex spp., Arum spp.) and even stem leaves (Alcea spp., Malva spp., Corylus avellana, Cydonia oblonga) are used.

Interestingly, when using leaves in which the lower (or both) surfaces are covered with trichomes (with varying densities) (e.g., Tussilago farfara, Tilia tomentosa, Salvia spp., Petasites hybridus), to avoid their unpleasant effect, only young leaves are normally collected; this approach also allows avoidance of the thorns of Cirsium arvense leaves and the glandular trichomes of Pelargonium quercetorum. Some of the species (Morus and Vitis spp.)

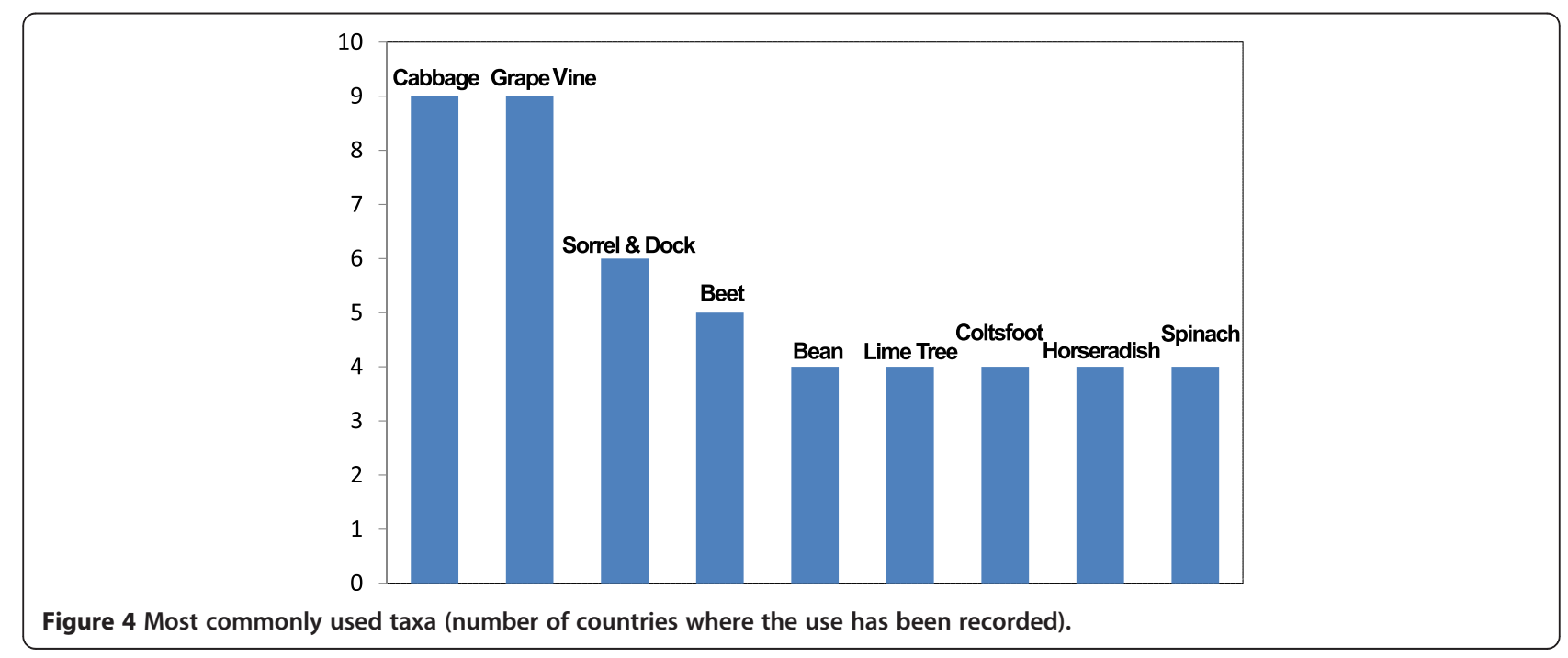


have well expressed heterophylly and thus, to identify the most suitable leaves, requires specific knowledge of the morphology and ecological plasticity of the species.

Regardless of the morphological characteristics of the leaves, most leaf types go through a preliminary heat treatment before being used as wrapping material, thus increasing their flexibility.

Some leaves (esp. cabbage, grape vine, and lime tree) are also preserved via lacto-fermentation to ensure their availability during winter.

\section{Most uncommon reports}

Apart from a few endemic species (Centaurea haradjianii, Rumex gracilescens and R. olympicus in Turkey), our findings also reveal the use in sarma of leaves that are uncommonly used as food items. A few of these are considered lightly toxic ingredients, such us potato leaves in North-Eastern Albania, leaves of Arum, Convolvulus, and Smilax species in Turkey, of Phytolacca americana in Macedonia (Figure 5), and of Tussilago farfara in Turkey and Romania.

Toxicity is removed via preliminary blanching of the leaves of Arum conophalloides, Arum dioscorides, Arum maculatum, Colocasia esculenta, Caltha palustris, and Smilax excelsa.

The consumption of these taxa could be linked to their broad leaf shape, large ecological, and seasonal availability in specific areas, but also to specific sensory characteristics, which in Southern Europe are also sometimes linked to perceived medicinal values [104].

It is possible to categorize the recorded leaves accordingly to their taste after cooking: a few (e.g., Allium spp.) may provide garlic- and leek-like tastes; others (e.g., Rumex, Corylus, Cydonia, Morus, Tilia, Vitis spp.) have a sour or a light astringent taste; or may provide bitter taste (e.g., potato leaves, Arctium, Centaurea, Cirsium, Petasites, Tussilago, and Lactuca spp.); a few provide cabbage-like (e.g., horseradish leaves, Caltha palustris), aromatic (Salvia sclarea), or even pungent tastes (Arum spp.). All of the aforementioned species are able to add a specific flavour to the final sarma taste and contribute in this way to an important diversification of this traditional elements of the festivity diets.

However, an important portion of the quoted leaves have a neutral taste (spinach, beans, beet, lime tree leaves), sometimes coupled with mucilaginous characteristics (e.g., Alcea and Malva spp.).

\section{Cross-cultural comparison}

Figure 6 shows the distribution of the plant biodiversity of sarma among the considered countries. Turkey has the greatest diversity of sarma leaves $(n=68$ taxa, representing $78 \%$ of the overall recorded plants), while the Balkan countries listed significantly fewer plants, with a richer sarma diversity in Bulgaria $(\mathrm{n}=16)$ and Romania $(\mathrm{n}=14)$. The biodiversity of the sarma leaves tends to significantly decrease towards the Mediterranean cultural area (Dalmatia/ Croatia) reflecting former borders of the Ottoman Empire. Only a small number of plants (16\%) were reported for more than one country (12). These are mainly cultivated edible greens (e.g., Armoracia rusticana, Beta vulgaris, Brassica oleracea, Lactuca sativa, Spinacia oleracea and their cultivars), with legumes (e.g., Phaseolus vulgaris), fruit trees and shrubs (e.g., Cydonia oblonga, Vitis spp.).
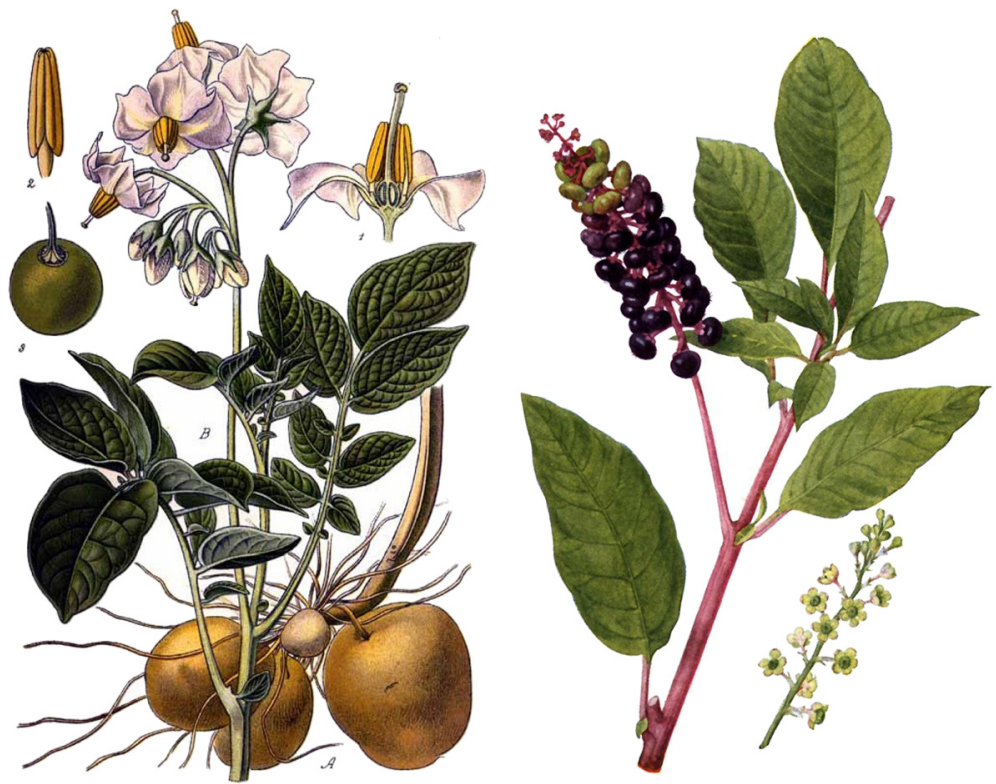

Figure 5 Unusual food ingredients used for preparing sarma: young potato and pokeberry (Phytolacca americana) leaves. 


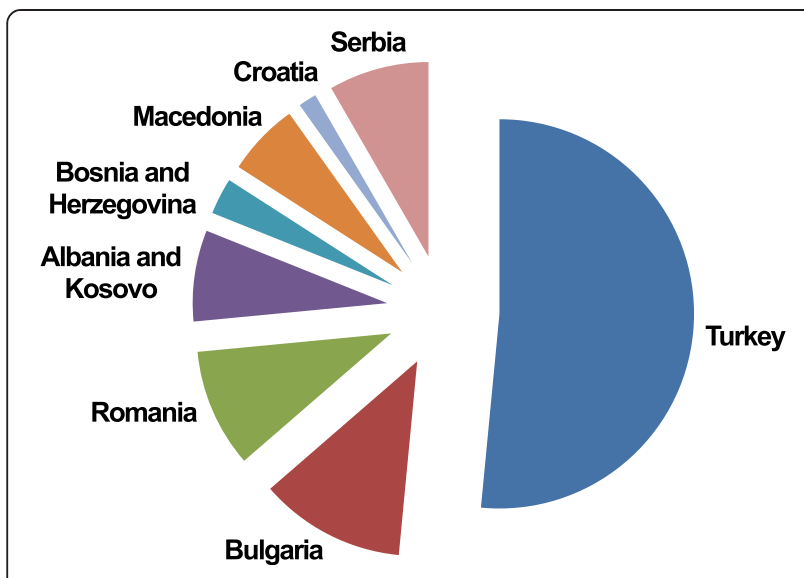

Figure 6 Biodiversity of sarma in the considered countries (according to the number of recorded plant taxa).

Among the quoted wild plants, dock and sorrel (Rumex spp.) predominate; however, Rumex spp. leaves are widely used also in other preparations in the local diets of Turkey and Balkan mountainous pastoralist communities [1] and represent important food items for populations that originated in Central Asia, as demonstrated by a recent study among the Tatars of Romania [61].

Most of the quoted wild plants are, however, wellknown in the studied areas as edible plants, and are used for preparing salads, soups, and pies $[1,7,8,21,22]$.

According to Table 1, the greatest diversity of sarma types are consumed within Turkey, between Western Anatolia (and Izmir and its surroundings, e.g., Allium ampeloprasum, Beta vulgaris, Lactuca sativa, Morus rubra, Phaseolus vulgaris, Rumex obtusifolius, and Spinacia oleracea) and Eastern Anatolia, especially Malatya and its surroundings (e.g., Beta vulgaris, Cydonia oblonga, Phaseolus vulgaris, and Lactuca sativa).

\section{The dynamism of sarma's cultural meanings}

Sarma leaves retain diverse cultural- and place-specific meanings for each of the studied areas, and these meanings have changed, and are most probably continuing to change, over time.

While the cultural meaning of sarma in the Ottoman (and then mainly Islamic) cuisines is indisputable, sarma seems to be also strongly related to traditional Orthodox festivity meals, especially in Bulgaria and Romania (e.g., Christmas Eve, All Souls' Day, and especially Easter) but also among the Roman-Catholic Croats.

For example, on Christmas Eve in Bulgaria and in the whole Orthodox Lent periods in Romania, vegetarian sarma represent the main dish.

Moreover, in the Bulgarian folk customs, the grape vine was mainly considered as the starting material (fruits) for producing wine; during the Communist period however, many Bulgarian workers moved to Northern African (Arabic) countries (e.g., Libya, Algeria), where they learned to prepare sarma from grape leaves where sarma is considered a typical Arabic meal (and also commonly used in Greece). Grape vine-based sarma became popular during that time and cabbage and grape leaves now represent the most commonly used sarma leaves of the Bulgarian cuisine.

Whereas the first cookbook written in the Bulgarian language (printed in 1870 in Istanbul [49]) included some sarma recipes in which hazelnut leaves were used and vine branches were placed at the bottom of the pot. Neither of these gastronomic uses were found in our field studies, nor in the primary folkloric sources of the twentieth century.

Finally, novel sarma plants, such as Reynoutria japonica in North-Western Romania, Colocasia esculenta in Turkey (Figure 7), and Phytolacca americana in Macedonia
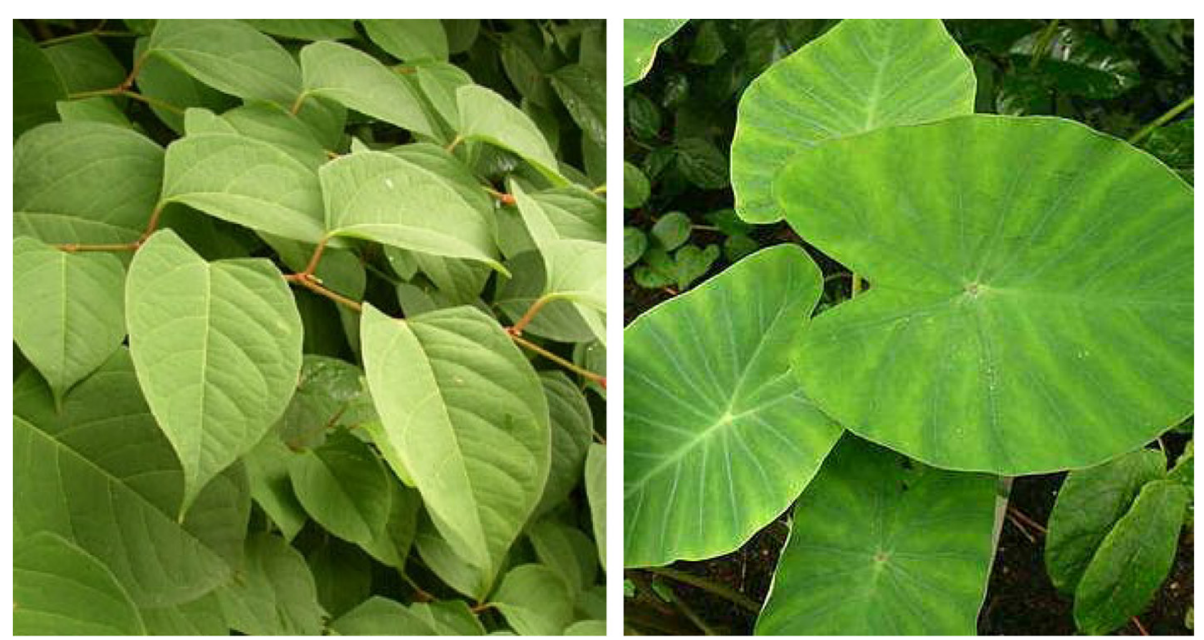

Figure 7 Novel sarma ingredients: Reynoutria japonica and Colocasia esculenta. 
demonstrate the dynamic nature of folk cuisines. Within certain eco-zones, these introduced plants have probably represented the most widely available plant resources, which may have led local populations to experiment with new ingredients in their cuisines. These novelties may have in turn diffused via cultural exchange into neighboring areas.

\section{Conclusion}

The findings of this study show a remarkable diversity of sarma preparations across the considered countries, stemming from an unexpectedly diverse selection of wild plant leaves.

Turkey retains approximately half of the entire sarma plant biodiversity recorded in the considered countries, thus confirming the strong link between this culinary preparation and the Ottoman cuisine of the last four centuries.

However, the cultural meanings of sarma also in the Balkan Orthodox customs, and notably in Bulgaria, Romania, and Serbia, is remarkable, and demonstrates the extremely dynamic and changeable nature of folk ethnobotanical practices.

The rationale behind the choice of the appropriate leaves for sarma include shape, size, texture, and the ecological and seasonal availability of specific plant leaves; moreover, the importance of taste (and possibly perceived medicinal values) in the choice of the most appropriate leaf wrap was evidenced. This medicinal evidence may also account for the use of lightly toxic plants; however, the human ecological significance of the consumption of these leaves should be clarified caseby-case, and by analyzing the specific historical, anthropological, and environmental contexts. For example, regarding the consumption of potato leaves (sometimes as sarma wrapping material, but also in other food contexts) that we recorded in a few villages in NorthEastern Albania and on the Macedonian side of Korab Mountain $[9,13]$, we propose that this might be the result of an extreme environmental adaptation by the local populations after the introduction of the potato crop (around the end of the nineteenth century). The subsequent demographic pressures may have forced locals to permanently inhabit inhospitable summer pastures, where the availability of edible greens in the first spring months (due to the severe winter climatic conditions) could have been extremely limited.

We believe that this rich ethnobiological heritage may be of interest to scholars and folkloric museums, and especially useful for re-evaluating local food niche markets and avant-garde gastronomic trends [105]. In fact, both of these trajectories are increasingly focused on reconsolidating the healthy and sustainable foods practices of folk cuisines, which are often linked with the 'sense-of-place' of a given biocultural oikos (a.k.a., terroir). At the same time, the valorization of reservoirs of ethnobotanical knowledge could have a tremendous impact upon the food sovereignty and health strategies of rural communities in South-Eastern Europe [106].

\section{Authors' contributions}

AP conceived the study; all authors provided the original field data and analyzed the primary literature in each considered country; $A P, A N$, and YD drafted the data analysis and - with $\measuredangle Ł$ - addressed the discussion of the data; AP wrote the first draft of the paper, on which also AN, YD, ŁŁ, and ZDS contributed. JF edited a previous version of the article. All authors read and approved the final manuscript.

\section{Acknowledgements}

Special thanks are due to all the study participants from the investigated research sites and to the reviewers, for their precious suggestions.

\section{Author details}

'Buca Faculty of Education, Dokuz Eylul University, 35150 Buca, Izmir, Turkey. ${ }^{2}$ Department of Botany, University of Sofia, Blvd. Dragan Tzankov, 1164 Sofia, Bulgaria. ${ }^{3}$ Department of Botany, Institute of Applied Biotechnology and Basic Sciences, University of Rzeszów, Werynia 502, 36-100 Kolbuszowa, Poland. ${ }^{4}$ Department of Ecology and Environmental Protection, Lucian Blaga University, Dr. Ioan Rațiu St. 5-7, Sibiu, Romania. ${ }^{5}$ Department for Pharmacognosy, Phytochemistry and Pharmaceutical Botany, Faculty of Pharmacy, University Ss. Cyril and Methodius, Skopje, Macedonia. ${ }^{6}$ Via Bertolina 79, I-12084 Mondovì (Cuneo), Italy. ${ }^{7}$ Department of Cellular and Molecular Medicine, University of Ottawa, Ottawa K1H 8 M5, Canada. ${ }^{8}$ Ottawa Hospital Research Institute, Chronic Disease Program, Ottawa K1Y 4E9, Canada. ${ }^{9}$ Department of Pharmacognosy, University of Pécs, Rókus 2, 7624 Pécs, Hungary. ${ }^{10}$ Institute for Biological and Environmental Research, University of Prishtina "Hasan Prishtina", Mother Teresa Str., 10000 Prishtinë, Republic of Kosovo. ${ }^{11}$ Department of Agrobotany, Faculty of Agriculture, University of Belgrade, Nemanjina 6, 11080 Zemun, Belgrade, Serbia. ${ }^{12}$ University of Gastronomic Sciences, Piazza Vittorio Emanuele 9, 12060 Bra/Pollenzo, Italy.

Received: 22 December 2014 Accepted: 20 January 2015

Published online: 03 April 2015

\section{References}

1. Pieroni A, Quave CL. Ethnobotany and biocultural diversities in the Balkans: perspectives on sustainable rural development and reconciliation. New York/Heidelberg: Springer; 2014

2. Lescureux N, Linnell JDC, Mustafa S, Melovski D, Stojanov A, Ivanov G, et al. Fear of the unknown: local knowledge and perceptions of the Eurasian lynx Iynx Iynx in western Macedonia. ORYX. 2011;45(4):600-7.

3. Lescureux N, Linnell JDC, Mustafa S, Melovski D, Stojanov A, Ivanov G, et al. The king of the forest: Local knowledge about European brown bears (Ursus arctos) and implications for their conservation in contemporary Western Macedonia. Conserv Soc. 2011;9(3):189-201.

4. Lescureux N, Linnell JDC. Knowledge and perceptions of Macedonian hunters and herders: the influence of species specific ecology of bears, wolves, and lynx. Hum Ecol. 2010;38(3):389-99.

5. Redžić S. Wild medicinal plants and their usage in traditional human therapy (Southern Bosnia and Herzegovina, W. Balkan). J Med Plant Res. 2010;4(11):1003-27.

6. Redžić S, Barudanovic S, Pilipovic S. Wild mushrooms and lichens used as human food for survival in war conditions; Podrinje - Zepa region (Bosnia and Herzegovina, W. Balkan). Res. Hum Ecol. 2010;17(2):175-87.

7. Redžić S. Wild edible plants and their traditional use in the human nutrition in Bosnia and Herzegovina. Ecol Food Nutr. 2006;45(3):189-232.

8. Nedelcheva A. An ethnobotanical study of wild edible plants in Bulgaria. Eurasia J BioSci. 2013;7:77-94.

9. Pieroni A, Rexhepi B, Nedelcheva A, Mustafa B, Hajdari A, Kolosova V, et al. One century later: the folk botanical knowledge of the last remaining Albanians of the upper Reka Valley, Mount Korab, Western Macedonia. J Ethnobiol Ethnomed. 2013;9:22.

10. Rexhepi B, Mustafa B, Hajdari A, Rushidi-Rexhepi J, Quave CL, Pieroni A Traditional medicinal plant knowledge among Albanians, Macedonians and 
Gorani in the Sharr Mountains (Republic of Macedonia). Gen Resour Crop Ev. 2013;60(7):2055-80.

11. Knight DM. Mushrooms, knowledge exchange and polytemporality in Kalloni, Greek Macedonia. Food, Culture \& Society. 2014;17(2):183-201.

12. Pieroni A, Nedelcheva A, Hajdari A, Mustafa B, Scaltriti B, Cianfaglione K, et al. Local knowledge on plants and domestic remedies in the mountain villages of Peshkopia (Eastern Albania). J Mt Sci. 2014;11(1):180-94.

13. Pieroni A, Cianfaglione K, Nedelcheva A, Hajdari A, Mustafa B, Quave CL. Resilience at the border: traditional botanical knowledge among Macedonians and Albanians living in Gollobordo, Eastern Albania. J Ethnobiol Ethnomed. 2014;10:31

14. Quave CL, Pieroni A. Fermented foods for food security and food sovereignty in the Balkans: a case study of the gorani people of Northeastern Albania. J Ethnobiol. 2014;34(1):28-43.

15. Pieroni A. Local plant resources in the ethnobotany of Theth, a village in the Northern Albanian Alps. Gen Resour Crop Ev. 2008;55(8):1197-214.

16. Pieroni A. People and plants in Lëpushë. Traditional medicine, local foods, and postcommunism in a North Albanian village. In: Pardo de Santayana M, Pieroni A, Puri R, editors. Ethnobotany in the new Europe: People, health and wild plant resources. New York/Oxford: Berghahn; 2010. p. 16-50.

17. Łuczaj $Ł$, Zovko-Končić M, Miličević T, Dolina K, Pandža M. Wild vegetable mixes sold in the markets of Dalmatia (southern Croatia). J Ethnobiol Ethnomed. 2013:9:2.

18. Łuczaj $Ł$, Fressel N, Perković S. Wild food plants used in the villages of the Lake Vrana Nature Park (northern Dalmatia, Croatia). Acta Soc Bot Pol. 2013;82(4):275-81.

19. Dolina K, Łuczaj Ł. Wild food plants used on the Dubrovnik coast (south-east Croatia). Acta Soc Bot Pol. 2014;83(3):175-81.

20. Pieroni A, Quave CL, Giusti ME, Papp N. "We are Italians!": the hybrid ethnobotany of a Venetian diaspora in Eastern Romania. Hum Ecol. 2012:40:435-51.

21. Dogan Y. Traditionally used wild edible greens in the Aegean Region of Turkey. Acta Soc Bot Pol. 2012;81(4):329-41.

22. Dogan Y, Baslar S, Ay G, Mert HH. The use of wild edible plants in western and central Anatolia (Turkey). Econ Bot. 2004;58(4):684-90.

23. Kargioglu M, Cenkci S, Serteser A, Evliyaoglu N, Konuk M, Kök MŞ, et al. An ethnobotanical survey of inner-west Anatolia. Turkey Hum Ecol. 2008;36(5):763-77.

24. Dogan Y, Ugulu I, Durkan N. Wild edible plants sold in the local markets of Izmir, Turkey. Pak J Bot. 2013;45(S1):177-84.

25. Sarper F, Akaydin G, Şimşek I, Yeşilada E. An ethnobotanical field survey in the Haymana district of Ankara province in Turkey. Turk J Bot. 2009;33(1):79-88

26. Simsek I, Aytekin F, Yesilada E, Yildirimli ş. An ethnobotanical survey of the Beypazari, Ayas, and Güdül district towns of Ankara Province (Turkey). Econ Bot. 2012;58(4):705-20.

27. Yerasimos M. 500 years of Ottoman cuisine [500 yıllık Osmanlı mutfağı]. Istanbul: Boyut; 2002.

28. Bilgin A. Refined tastes in a refined place: eating habits in the Ottoman Palace during the 15th-17th centuries. 2011. http://www.turkish-cuisine.org/ english/pages.php?Parent|D=1\&FirstLevel=9\&SecondLevel=107\&LastLevel=109

29. Fragner B. From the Caucasus to the roof of the world: a culinary adventure. In: Zubaida S, Tapper R, editors. A taste of thyme: culinary cultures of the Middle East. London and New York: I.B.Tauris; 1994. p. 49-62.

30. Savkay T. Osmanlı mutfağı [Ottoman cuisine]. Şekerbank T.A.S.:: Istanbul; 2000.

31. Karaosmanoglu D. Cooking the past: the revival of ottoman cuisine. Montreal: McGill University; 2006.

32. Akkor MO. Osmanlı mutfağı [Ottoman cuisine]. sstanbul: Kaynak Yayınları; 2014.

33. Dernschwam H, Babinger F. Hans Dernschwam, Tagebuch einer Reise nach Konstantinopel und Kleinasien (1553-1555) [Hans Dernschwam, Diary of a Travel to Constainople and Minor Asia (1553-1555)]. München/Leipzig: Duncker \& Humblot; 1923.

34. Karaosmanoglu D. Eating the past: multiple spaces, multiple times -performing 'Ottomanness' in Istanbul. Int J Cult Stud. 2009;12(4):339-58.

35. The plant list (Version 1.1). 2013. http://www.theplantlist.org/

36. Sejdiu S. Fjalorth ethnobotanik i shqipes [Ethnobotanical Albanian dictionary]. Rilindja: Prishtina; 1984.

37. Mustafa B, Hajdari A, Krasniqi F, Hoxha E, Ademi H, Quave CL, et al. Medical ethnobotany of the Albanian Alps in Kosovo. J Ethnobiol Ethnomed. 2012;8:6.

38. Pieroni A, Dibra B, Grishaj G, Grishaj I, Maçai SG. Traditional phytotherapy of the Albanians of Lepushe, Northern Albanian Alps. Fitoterapia. 2005;76(3-4):379-99.
39. Mustafa B, Hajdari A, Pajazita Q, Syla B, Quave $C L$, Pieroni A. An ethnobotanica survey of the Gollak region, Kosovo. Gen Resour Crop Evol. 2012;59(5):739-54.

40. Redžić S. The ecological approach to ethnobotany and ehnopharmacology of population in Bosnia and Herzegovina. Collegium Anropol. 2007;31(3):869-90.

41. Šarić-Kundalić B, Dobeš C, Klatte-Asselmeyer V, Saukel J. Ethnobotanical survey of traditionally used plants in human therapy of east, north and north-east Bosnia and Herzegovina. J Ehnopharmacol. 2011;133(3):1051-76.

42. Šarić-Kundalić B, Dobeš C, Klatte-Asselmeyer V, Saukel J. Ethnobotanical study on medicinal use of wild and cultivated plants in middle, south and west Bosnia and Herzegovina. J Ethnopharmacol. 2010;131(1):33-55.

43. Šarić-Kundalić B, Fritz E, Dobeš C, Saukel J. Traditional medicine in the pristine village of Prokoško lake on Vranica Mountain, Bosnia and Herzegovina. Sci Pharm. 2010;78(2):275-90

44. Kolev N. Balgarska ethnografia [Bulgarian ethnography]. Nauka i izkustvo: Sofia; 1987.

45. Krasteva-Blagoeva E. Taste in the Balkans: food and identity [Vkusat na balkanite: hrana i identichnost]. Bulgarian Folklore. 2010;XXXVI(1):7-20.

46. Marinov D. Izbrani proizvedenija. 1.2 Religiozni narodni obichai [Selected works. 1.2 Religious folk customs]. Iztok-Zapad: Sofia; 2003.

47. Markova M. Hrana i hranene: mezhdu priroda i kultura [Food and nutrition: Between nature and culture]. Sofia: Profesor Marin Drinov Academic Publishing House; 2011.

48. Pavlov I. Prisastvia na hraneneto po balgarskite zemi prez XV-XIX vek [Presence of food in the Bulgarian lands in XV-XIX century]. Sofia: Profesor Marin Drinov Academic Publishing House; 2001.

49. Slaveikov PR. Gotvarska kniga [Cookbook]. Pechatnica Makedonia: Istanbul; 1870

50. Vakarelski K. Etnografia na Bulgaria [Ethnography of Bulgaria]. Izd. Nauka i Izkustvo: Sofia; 1977

51. Cvitanic M. Culture and customs of Croatia. Santa Barbara: Greenwood Publishing Group; 2011.

52. Pieroni A, Giusti ME. The remedies of the folk medicine of the Croatians living in Cićarija, northern Istria. Collegium Antrop. 2008;32(2):623-7.

53. Pieroni A, Giusti ME, Münz H, Lenzarini C, Turković G, Turković A Ethnobotanical knowledge of the Istro-Romanians of Žejane in Croatia. Fitoterapia. 2003;74(7-8):710-9.

54. Kołodziejska-Degórska I. Mental herbals - A context-sensitive way of looking at local ethnobotanical knowledge: Examples from Bukovina (Romania). Trames. 2012;16(3):287-301.

55. Papp N, Birkás-Frendl K, Bencsik T, Stranczinger S, Czégényi D. Survey of traditional beliefs in the Hungarian Csángó and Székely ethnomedicine in Transylvania, Romania. Rev Bras Farmacogn. 2014;24(2):141-52.

56. Papp N, Birkás-Frendl K, Farkas A, Pieroni A. An ethnobotanical study on home gardens in a Transylvanian Hungarian Csángó village (Romania). Gen Resour Crop Evol. 2013:60:1423-32.

57. Péntek J, Szabó TA. Ember és növényvilág. Kalotaszeg növényzete és népi növényismerete [Plant kingdom and traditional human life in Călata area, Romania]. Kriterion: Bucharest; 1985.

58. Tițã l, Mogoşanu GD, Tițã MG. Ethnobotanical inventory of medicinal plants from the South-West of Romania. Farmacia. 2009:57(2):141-56.

59. Butura V. Enciclopedie de etnobotanică românească [Encyclopaedia of Romanian ethnobotany]. Editura ştiințifica şi enciclopedică: Bucharest; 1979.

60. Kołodziejska-Degórska I. Z czego 'uwarić harbatę'? Dzikie rośliny jadane w polskich wsiach na południowej Bukowinie (Rumunia) [What to use for tea: Wild food plants in Polish villages of Southern Bukovina (Romania)]. In: Luczaj L, editor. Materiały z konferencji Dzikie rośliny jadalne-zapomniany potencjał przyrody, Przemyśl-Bolestraszyce 13 września 2007r [Wild edible plants, the forgotten potential of nature Conference proceedings, Przemyśl-Bolestraszyce, 13 September 2007]. Przemyśl (Poland): Arboretum i Zakład Fizjografii Bolestraszyce w Bolestraszycach; 2008. p. 219-26.

61. Pieroni A, Nedelcheva A, Dogan Y. Local knowledge of medicinal plants and wild food plants among Tatars and Romanians in Dobruja (South-East Romania). Gen Resour Crop Evol, in press. doi:10.1007/s10722-014-0185-3.

62. Drăgulescu C. Pflanzenheilmittel der rumänischen Volksmedizin [Plant remedies of the Romanian folk medicine]. Barthel \& Barthel: Nendeln; 2006.

63. Drăgulescu C. Botanica populară în Tara Făgărașului [Folk botany in the region Făgăraş]. Constant: Sibiu; 1995.

64. Łuczaj Ł, Kosiek T, Stawarczyk K. Hebda K, Kotowski M. Liście używane na gołąbki przez Ukraiców w rumuńskim Maramuresz: notatka etnobotaniczna [Leaves used for sarma by the Ukrainians in Romania's Maramures: ethnobotanical notes]. Etnobiologia Polska. 2014;4:83-7. 
65. Roman RA. Bucate, vinuri și obiceiuri românești [Dishes, wines and Romanian traditions]. Paideia: Bucharest; 2001.

66. Băcescu M. Nume de plante [Plant names]. Revista critică. 1931;V(2-3):111-51.

67. Drăgulescu C. Plante comestibile din România [Edible plants in Romania]. Alma Mater Sibiu: Sibiu; 2008.

68. Marian SF. Botanica poporană română [Romanian folk botany]. Editura Academiei Române: Suceava; 2010.

69. Drăgulescu C. Botanica populară românească în sudul Transilvanie [Romanian folk botany in Southern Transylvania]. Sibiu: Edit. Univ. "Lucian Blaga"; 2013.

70. Abay G, Kılıc A. Pürenbeleni ve Yanıktepe (Mersin) yörelerindeki bazı bitkilerin yöresel adları ve etnobotanik özellikleri [Local names and ethnobotanical features of some plants in the Pürenbeleni and Yanıktepe (Mersin) regions]. OT Sistematik Botanik Dergisi. 2001;8(2):97-104.

71. Akaydın G, Şimşek I, Arıtuluk ZC, Yeşilada E. An ethnobotanical survey in selected towns of the Mediterranean subregion (Turkey). Turk J Biol. 2013;37:230-42.

72. Baytop T. Türkçe bitki adları sözlüğü [Turkish dictionary of plant names]. Türk Dil Kurumu Yayınları: Ankara; 2007.

73. Dogan Y, Ugulu I. Medicinal plants used for gastrointestinal orders in some districts of Izmir Province, Turkey. Studies on Ethno-Medicine. 2013;7:149-62

74. Balos MM. Zeytinbahçe ile Akarçay arasında kalan (Birecik) bölgenin florası ve etnobotanik özellikleri [The flora and ethnobotany of the region between Zeytinbahçe and Akarçay (Birecik)], MSc thesis. Şanlıurfa: Harran University; Department of Biology; 2007.

75. Emre Bulut G. Ethnobotanical investigations in Bayramiç (Çanakkale) [Bayramiç (Çanakkale) yöresinde etnobotanik araştırmalar], MSc thesis. Istanbul: Marmara University; Department of Pharmaceutical Botany; 2008.

76. Gençay F. Cizre (Şırnak)'nin etnobotanik özellikleri [Ethnobotanical aspects of Cizre (Şırnak)], MSc thesis. Van: Yüzüncü Yıl University; Department of Biology; 2007

77. Güneş S. Karaisali (Adana) ve köylerinde halkın kullandiği doğal bitkilerin etnobotanik yönden arastırılması [Ethnobotanical investigation on the use of plants in the villages of Karaisali (Adana)], MSc thesis. Niğde: Niğde University; Department of Biology; 2010.

78. Kaval I. Geçitli (Hakkari) ve çevresi'nin etnobotanik özellikleri The ethnobotany of Geçitli (Hakkari) and its vicinity], MSc thesis. Van: Yüzüncü YIl University; Department of Biology; 2011.

79. Aras N. 'Sarma' and 'Dolma': rolled and stuffed dishes as therapy tools for the Anatolian women in the kitchen. In: McWilliams M, editor. Wrapped and stuffed foods. Proceedings of the oxford symposium on food and cookery 2012. Totnes, UK: Prospect Book; 2013. p. 57-67.

80. Yücel E, Güneyy F, Yücel ŞI. The wild plants consumed as a food in Mihalıççık district (Eskişehir/Turkey) and consumption forms of these plants. Biol Div Conserv. 2010;3(3):158-75.

81. Kızılarslan C. İmit Körfezi'nin güney kesiminde etnobotanik bir araştırma [An ethnobotanical survey in the southern part of the Gulf of Izmit], MSc thesis. Istanbul: Istanbul University; Department of Pharmaceutical Botany; 2008.

82. Koçyigit MF, Özhatay NF. The wild edible and miscellaneous useful plants in Yalova province (northwest Turkey). J Fac Pharm Istanbul Univ. 2009;40:19-29.

83. Koçyiğit M. Yalova ilinde etnobotanik çalışma [An ethnobotanical study in the Yalova province], MSc thesis. Istanbul: Istanbul University; Department of Pharmaceutical Botany; 2005.

84. Koyuncu O. Geyve (Sakarya) ve çevresinin floristik ve etnobotanik açıdan incelenmesi [Investigations of floristic and etnobotanical aspects of Geyve (Sakarya) and its environment], MSc thesis. Eskişehir: Eskişehir Osmangazi University; Department of Biology; 2005.

85. Vural G. Honaz Dağı ve çevresindeki bazı doğal bitkilerin etnobotanik özellikleri [Ethnobotanical features some of the wild plants on the Honaz mountain and its environment], MSc thesis. Afyonkarahisar: Afyon Kocatepe University; Department of Biology; 2008

86. Tugay O, Bağcı I, Ulukuş D, Özer E, Canbulat MA. Wild plants using as food of Kurucuova Town (Beyşehir, Konya/Turkey). Biol Div Conserv. 2012;5:140-5.

87. Demirci S. Andııın (Kahramanmaraş) ilçesinde etnobotanik bir araştırma [Ethnobotanical study in Andirin (Kahramanmaras) district], MSc thesis. Istanbul: Istanbul University; Department of Pharmaceutical Botany; 2010.

88. Kızılarslan Ç, Özhatay N. An ethnobotanical study of the useful and edible plants of İzmit. Marmara Pharm J. 2012;16(3):194-200.

89. Çakılcıoğlu U, Türkoğlu I, Murat K. Harput (Elazığ) ve çevresinin etnobotanik Özellikleri [Ethnobotanical features of Harput (Elazig) and its vicinity]. Doğu Anadolu Bölgesi Araştırmaları (Daum) Dergisi. 2007;5(2):22-8.
90. Deniz L, Serteser A, Kargığlu M. Uşak Üniversitesi ve yakın çevresindeki bazı bitkilerin mahalli adları ve etnobotanik özellikleri [Local names and ethnobotanical features of some plants in Usak University (Usak) and its near vicinity]. Deniz, Serteser ve Kargıoğlu/AKÜ Fen Bilimleri Dergisi. 2010;1:57-72.

91. Elçi B, Erik S. Güdül (Ankara) ve çevresinin etnobotanik özellikleri [Ethnobotanical properties of Güdül (Ankara) and near environs]. Hacettepe Üniversitesi, Eczaclık Fakültesi Dergisi. 2006;26(2):57-64.

92. Ozbucak TB, Kutbay HG, Akcin OE. The contribution of wild edible plants to human nutrition in the Black Sea region of Turkey. Ethnobot Leaflets. 2006;10:98-103.

93. Simsek I, Aytekin F, Yeşilada E, Yıldırımlı S. Anadolu'da halk arasında bitkilerin kullanıı ı̧ amaçları üzerinde etnobotanik bir çalışma [An ethnobotanical study among the population on the purpose of plant utilization in Anatolia]. In: Başer KHC, Kırımer N, editors. 14. Bitkisel İlaç Hammaddeleri Toplantısı Bildirileri (14. Herbal Pharmaceutical Raw Materials Conference Proceedings): 29-31 May 2002; Eskişehir. Eskişehir: Eskisehir University; 2002. p. 434-57.

94. Arık M. Korkut (Muş) İlçesi ve köylerinin faydalı bitkileri [Useful plants of Korkut town (Muş) and its villages], MSc thesis. Van: Yüzüncü Yıl University; Department of Biology; 2003.

95. Mükemre M. Konalga, Sırmalı, Dokuzdam Köyleri (Çatak-Van) ve çevrelerinin etnobotanik özellikleri [Ethnobotanical features of Konalga, Sırmalı, Dokuzdam Villages (Çatak/Van) and their vicinity], MSc thesis. Van: Yüzüncü YIl University; Department of Biology; 2013.

96. Mart S. Bahçe ve Hasanbeyli (Osmaniye) halkının kullandığı doğal bitkilerin etnobotanik yönden araştırılması [An ethnobotanical investigation of the natural plants using by inhabitants in Bahçe and Hasanbeyli districts of Osmaniye Province], MSc thesis. Adana: Çukurova University; Department of Biology; 2006.

97. Doğru Koca A, Yıldıımlı Ş. Ethnobotanical properties of Akçakoca District in Düzce (Turkey). Hacettepe J Biol Chem. 2010;38(1):63-9.

98. Poyraz Kayabaşı N. Manyas ve köylerinde etnobotanik bir çalışma [The ethnobotanical examine in the villages of Manyas and Manyas], MSc thesis. Balıkesir: Balıkesir University; Department of Biology; 2011.

99. Alpaslan Z. The ethnobotanical properties of Ergan mountain (Erzincan) [The ethnobotanical properties of Ergan Mountain (Erzincan)], MSc thesis. Erzincan: Erzincan University; Department of Biology; 2012.

100. Kocyigit M, Ozhatay N. The wild edible and miscellaneous useful plants in Yalova province (northwest Turkey). J Fac Pharm Istanbul. 2009;40:19-29.

101. Ertug F. Wild edible plants of the Bodrum area (Mugla, Turkey). Turk J Bot. 2004;28:161-74.

102. Yüzbaşıoğlu E. Reşadiye (A6, Tokat, Türkiye) ve çevresinin etnobotaniği [Ethnobotany of Reşadiye-Tokat]. MSc thesis. Sanakkale: Onsekiz Mart University, Department of Biology; 2010.

103. Tuzlacı E. Türkiye'nin yabani besin bitkileri ve ot yemekleri [Wild edibles and herbal dishes in Turkey]. Alfa Yayınları: Istanbul; 2011.

104. Pieroni A, Nebel S, Quave C, Münz H, Heinrich M. Ethnopharmacology of liakra, traditional weedy vegetables of the Arbëreshë of the Vulture area in southern Italy. J Ethnopharmacol. 2002;81(2):165-85.

105. Łuczaj Ł, Pieroni A, Tardío J, Pardo-de-Santayana M, Sõukand R, Svanberg I, et al. Wild food plant use in 21st century Europe: the disappearance of old traditions and the search for new cuisines involving wild edibles. Acta Soc Bot Pol. 2012;81(4):359-70.

106. Quave $\mathrm{CL}$, Pieroni A. Reservoir of ethnobotanical knowledge informs resilient food security and health strategies in the Balkans. Nature Plants. 2015. article number 14021

\section{Submit your next manuscript to BioMed Central and take full advantage of:}

- Convenient online submission

- Thorough peer review

- No space constraints or color figure charges

- Immediate publication on acceptance

- Inclusion in PubMed, CAS, Scopus and Google Scholar

- Research which is freely available for redistribution 